\title{
NOTES ON THE GENUS USNEA DILL. EX ADANSON
}

\author{
Philippe CLERC $\star$
}

\begin{abstract}
Usnea quercina Bystrek \& Górzyńska, based on heterogeneous type material, is lectotypified and becomes a synonym of $U$. wirthii $\mathbf{P}$. Clerc. Usnea wirthii is new for South America. A distribution map of $U$. madeirensis Motyka (Syn. U. silesiaca Motyka) in Europe is given. Usnea hesperina Motyka (Syn. U. elongata Motyka, U. schadenbergiana Göpp \& Stein, U. subgracilis Vain., U. subplicata (Vain.) Motyka) is new for Africa, Asia and South America. Usnea hirta (L.) F. H. Wigg. (Syn. U. commata Motyka, U. foveata Vain., U. leprosa Motyka) is new for Africa. Usnea subscabrosa Nyl. ex Motyka (Syn. U. santae-annae Motyka) is new for South America. The holotype of $U$. marocana Motyka (=U. mutabilis Stirt.) was found in $\mathrm{LBL}$.

C 1997 The British Lichen Society
\end{abstract}

\section{Introduction}

Motyka (1936-1938), in establishing his species concept in the genus Usnea, was influenced to a large extent by geographic criteria (Clerc 1994), i.e. the same species common to different continents was described as different taxa. Consequently many species with a worldwide distribution have been described several times under different names. Such names belonging to the same taxon were even sometimes included in different sections of Motyka's systematic arrangement, as shown in this article for $U$. hesperina.

In 1995 I had, for the first time, the opportunity to work in J. Motyka's herbarium in Lublin (LBL), as well as in those of E. Acharius (H-ACH) and W. Nylander (H-NYL) in Helsinki. Studying the original material of several taxa has had many taxonomic consequences, some of which are reported here.

\section{Materials and Methods}

All material has been studied with thin-layer chromatography (Culberson \& Ammann 1979) with modified solvent B (Culberson \& Johnson 1982). Anatomical measurements of the cortex (C), medulla (M) and central axis (A) were established according to the method given in Clerc (1984a)

\section{Results}

\section{Usnea hesperina Motyka}

Lich. Gen. Usnea Stud. Monogr., Pars Syst. 2: 383 (1938); type: Espagne (Spain), Iles Canaries, Tenerife, La I.aguna, Monte Las Mercedes, Lomo del Boqueron, 740-780 m, dans la pente boise en exp. SW, Laurisylva-Fayal-Brezal, sur les branches de Laurus, 12 ix 1986, P. Clerc (G--neotype, selected here); $\% \mathrm{C} / \% \mathrm{M} / \% \mathrm{~A}: 9 \cdot 5 / 24 / 34$; chemistry: usnic and protocetraric acids.

*Conservatoire et jardin botaniques, $1 \mathrm{ch}$. de l'Impératrice, Case postale 60, 1292 Chambésy/GE, Switzerland. 
Usnea elongata Motyka, Lich. Gen. Usnea Stud. Monogr., Pars Syst. 2: 411 (1938); type: Chile, Magualua, Jamuco, 1906, Morton Middleton (S!-holotype); \%C/\%M/\%A: 10/1647; chemistry: usnic and protocetraric acids.

Usnea hesperina subsp. liturata Motyka, Lich. Gen. Usnea Stud. Monogr., Pars Syst. 2: 384 (1938); type: Gallia, Morbihan, forêt de Camors, 1931, Des Abbayes (LBL!-holotype); \%C $\% \mathrm{M} \% \mathrm{~A}: 11 \cdot 5 / 19 \cdot 5 / 37$; chemistry: usnic and protocetraric acids.

Usnea schadenbergiana Göpp. \& Stein, 60. Fahresber. Schles. Ges. Vaterl. Cult.: 229 (1883); type: Ins. Philippinae, Siriban in Mindanao, Schadenberg (LBL!-holotype); \%C/1\%W/1/\%A: $9 / 15 / 52$; chemistry: usnic, stictic, constictic, cryptostictic, menegazziaic and norstictic acids.

Usnea subplicata (Vain.) Motyka, Lich. Gen. Usnea Stud. Monogr., Pars Syst. 2: 558 (1938); Usnea gracilis var. subplicata Vain., Ann. Acad. Sci. Fenn., Ser. A 6: 7 (1915); type: Jamaica, ad ramos arborum, 1906, Boergesen (TUR-V 527!-holotype); \%C/\%M/\%A: 11.513 .550 ; chemistry: usnic and protocetraric acids.

Usnea subgracilis Vain., Ann. Acad. Sci. Fenn., Ser. A 6: 7 (1915); type: Jamaica, in ramibus arborum, 1906, Boergesen (TUR-V 513!-holotype); \%C/\%M/\%A: 12.5/16/43; chemistry: usnic and protocetraric acids.

Usnea hesperina is one of the most characteristic of the pendulous Usnea species, with: cylindrical branches that are never ridged or foveolated, and are distinctly and densely annulated close to the pale basal part; long and curved fibrils, with few to many pseudocyphellae that may turn into soralia (isidiate or not) especially near the apices; a mat cortex, a thin and compact medulla and a thick central axis. Unfortunately the holotype specimen could not be found in LBL. The neotype selected here fits very well with Motyka's concept and corresponds to the protocetraric strain, which is the only chemotype previously known to occur in Europe, North America, Cuba and Jamaica (Motyka 1936-1938; Clerc unpublished). The original material of $U$. elongata, $U$. schadenbergiana, $U$. subgracilis and $U$. subplicata fits very well within the morphological variation of $U$. hesperina as I know it from Europe, northern America and the Canary Islands. The second species diverges chemically with the stictic acid complex in the medulla. Usnea hesperina is then new for Asia (U. schadenbergiana), Africa (see selected specimen) and South America ( $U$. elongata). A proposal will be made elsewhere to conserve $U$. hesperina against $U$. schadenbergiana and $U$. subgracilis.

It is worth mentioning that Motyka (1936-1938) put $U$. hesperina and $U$. schadenbergiana in sect. Elongatae, subsect. Longissimae, but $U$. elongata into sect. Elongatae, subsect. Ceratinae. Furthermore, both $U$. subplicata and $U$. subgracilis were placed in sect. Glabratae, subsect. Ossoleucae. This and other examples (Clerc unpublished) show that the systematic arrangement, as developed by Motyka, based on environmentally induced modifications of characters (e.g. colour and length of thallus, density of ramifications, shape of papillae) is strongly artificial and therefore does not reflect phylogeny within the genus. More work on Usnea species at world level is needed to infer a new hypothesis.

Selected specimen examined: South Africa: Cape: Wynberg distr. E slopes of Table Mt. along Sekeleton stream, on bark, $2000 \mathrm{ft}, 6$ xii 1953, Almborn (LBL as $U$. promontonii Mot.); chemistry:: usnic and protocetraric acids.

\section{Usnea hirta (L.) F. H. Wigg}

Prim. Fl. Hols. 91 (1780); type: Sweden, s. coll. in Fries, Lich. Suec. Exsicc. No. 150 (UPS), type. cons. prop. (Jorgensen et al. 1994b). 
Usnea comugata Motyka, Lich. Gen. Usnea Stud. Monogr., Pars Syst. 1: 105 (1936); type: Abissnia (Ethiopia), Podopolani, ad Euphorbias, 17 iv 1894, Schweinfurth (LBL! -holotype); $\%$ C $\%$ M $\%$ A: 2.5/42/11; chemistry: usnic and salazinic acids.

Lsnea foreata Vain., Amn. Acad. Sci. Fenn., Ser. A 27: 67 (1928); type: Fennia, Ik. (Russia, Leningrad Region), Sakkola, Kylmäoja, in Betula, 1917, Räsänen (TUR-V 377!-lectotype); " \%M\% $\%$ : 2.5/39.5/16; chemistry: usnic acid.

Unnea leprosa Motyka, Lich. Gen. Usnea Stud. Monogr., Pars Syst. 1: 106 (1936); type: (South Africa), Transvaal, Lydenburg, arboricola, Willms (H-NYL 36562!-holotype); \%C/\%M/\%A: 4.53815 ; chemistry: usnic and salazinic acids.

Usnea raniolosa Motyka, Lich. Gen. Usnea Stud. Monogr., Pars Syst. 1: 104 (1936); type: U.S.A., New Mexico, Hermit Peak prope Las Vegas, corticola, 1930, Brouard (LBL!holotype)

Usnea hirta is a species of worldwide distribution with extensive morphological variability as shown by the numerous subspecies recognized by Motyka (1936-1938). In Europe, $U$. hirta is distinguished by deformed branches, a pale base, the usual absence of papillae, the minute and usually abundantly isidiate pseudocyphellae that may turn into soralia, a thin $(2-5 \%)$ and glossy cortex and a lax medulla. The North American specimens represented by $U$. variolosa fit very well within the morphological variation of the European $U$. hirta. So far, $U$. hirta has been shown to have two chemical strains, one with usnic acid and murolic acid (Clerc 1987a) and the other with usnic, norstictic acids and usually fatty acids (murolic acid group?) (Halonen \& Puolasmaa 1995). The holotype of the African U. leprosa has salazinic acid but morphologically differs little from $U$. hirta. Many European species that have been well circumscribed chemically, have more recently been shown to have much larger chemical variability outside Europe (Halonen et al. unpublished). Swinscow \& Krog (1975) indicated five chemoraces for U. leprosa, although they probably misunderstood this taxon, which is not closely related to U. undulata. The East African galbinic acid chemorace probably does not even belong to $U$. leprosa. Except for the basal part, which is black in some specimens, $U$. corrugata is morphologically identical with $U$. hirta. One specimen collected in Ethiopia has norstictic acid and fatty acids of the murolic acid group. As a consequence $U$. hirta is considered here as new to Africa. The type specimens of $U$. igniaria Mot. (South America) and U. inermis Mot. (Australia) have not been examined by me but descriptions given by Motyka (1936-1938) and Walker (1985) leave few doubts about their resemblance to $U$. hirta.

Halonen \& Puolasmaa (1995) discussed $U$. foveata, synonymizing it with $U$. barbata sensu Jorgensen et al. (1994b). There is no doubt, as already stated by Clerc (1987a), that foveoles are environmentally induced and that $U$. foveata is thereby only a phenotype of $U$. hirta. All diagnostic characters mentioned above are present, as for instance the thin (5\%) and glossy cortex, which corresponds better with $U$. hirta than with $U$. barbata s. lat. Halonen \& Puolasmaa (1995) mentioned the presence of some papillae on the thickest branches of the holotype specimen of $U$. foveata as an indication for $U$. barbata s. lat. However, species that are reported in the literature to have no papillae sometimes produce a few papillae, as Myllys (1994) showed for U. glabrata (Ach.) Vain. 


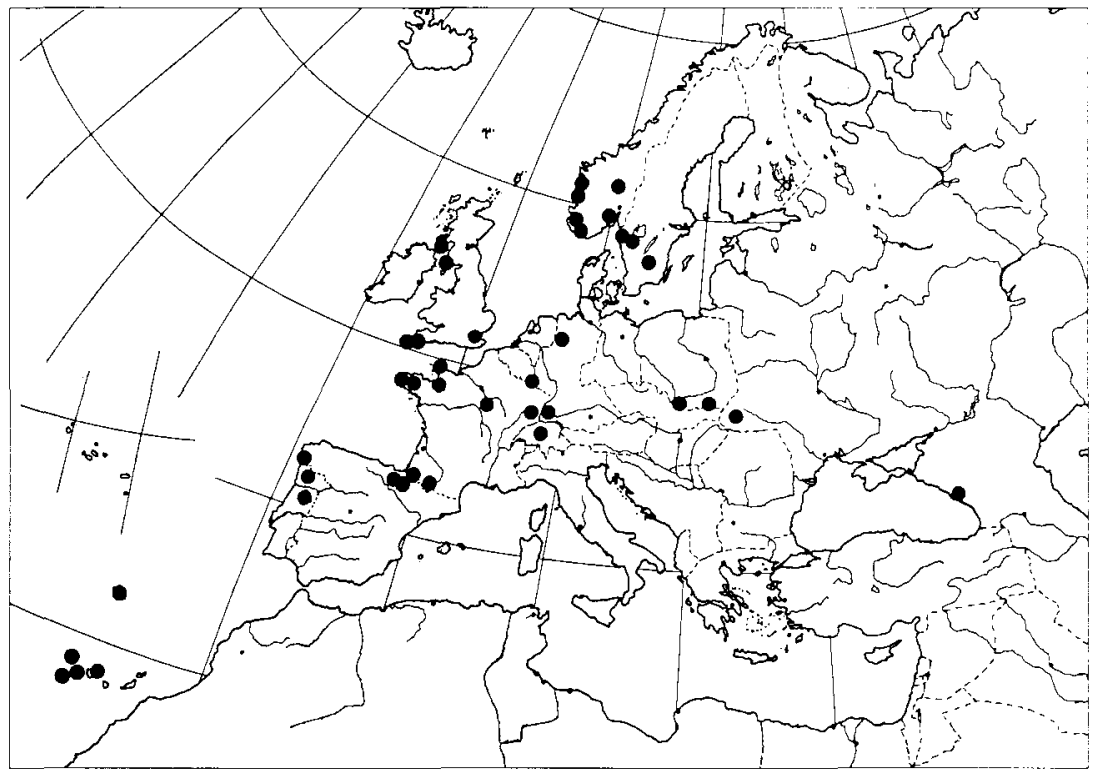

FIG. 1. Known distribution of Usnea madeirensis Motyka in Europe.

\section{Usnea madeirensis Motyka}

In Tav., Revista Biol. (Lisbon) 4: 131-134 (1964); type: Madeira, Paul da Serra, below Rabaçal and bica de Cana, on the branches, $1400 \mathrm{~m}, 15 \mathrm{v} 1952$, Persson (S!-holotype); $\% \mathrm{C} \% \mathrm{M} \% \mathrm{~A}$ : 12/12.5/50; chemistry: usnic and salazinic acids.

Usnea silesiaca Motyka, Wydaw. Muz. Słask. Katowicach. Dzial 3(2): 19 (1930); type: Poland, Beskidy Slaskie, Grabowa, na buku (Fagus) w bukowym lesie, 16 viii 1928, Motyka (LBL! - holotype); \%C/\%M/\%A: 11/9/60; chemistry: usnic and salazinic acids.

Because the main diagnostic characters were not given by Motyka (1930) in the protologue, the real identity of $U$. silesiaca remained unknown until the original material could be studied. Usnea silesiaca (shrubby morphotype) and $U$. madeirensis (pendulous morphotype) match very nicely in their main characters, with the exception of the habitus: extended black pigmentation in the basal part of the thallus with numerous annulations, soralia type (see Clerc 1987 b, fig. E, and Clerc 1991, fig. 3), cortex thick (9-14\%) and matt, medulla very thin (7-12\%) and compact, with salazinic acid (Clerc 1991). Usnea madeirensis is therefore a later homonym of $U$. silesiaca and a proposal to conserve $U$. madeirensis will be made elsewhere.

Bystrek (1970) and Bystrek et al. (1981), respectively, discussed the distribution of $U$. silesiaca in Europe and around Lublin in Poland, mainly on the basis of specimens housed in LBL. My examination of the specimens collected in Poland revealed that only two of the Polish specimens actually represent the species discussed here (see Fig. 1 and selected specimens). It seems that $U$. madeirensis is now extinct in Poland (J. Bystrek and H. Wojcak, pers. comm.). It is a most threatened species in Europe (Clerc 1991). 
Selected specimens examined: Poland: Beskid Zachodni: Runek koło Krynicy, na buku, 22 vii 1955, Tatarkiervicz (LBL). - Ukraine: Karpaty Wschodnie: Czarnohora, Pożyżewska, na świerkach i Picea, 1934, Motyka (LBL); Czarnohora, Pierwotny, las świerkowy na Pożyżewskiej, 1934, Motyka (LBL);

\section{Usnea mutabilis Stirt.}

Scott. Naturalist 6: 107 (1881); type: U.S.A., Alabama, Cedar villa, Mrs Hawley (BM!-holotype); chemistry: no substances demonstrated (label from M. Hale, 1977).

Usnea marocana Motyka, Lich. Gen. Usnea Stud. Monogr., Pars Syst. 2: 359 (1938); type: Maroc (Morocco), Camp Monod, arboricola, 1912, Mouret (LBL!-holotype); \%C/\%M/\%A: 6.5/29/29; chemistry: usnic acid and fatty acids of the murolic acid group.

As the original material in Bouly de Lesdain's herbarium was destroyed during the Second World War, Clerc (1994) chose a neotype for U. marocana. However when studying the original material of this taxa, J. Motyka kept a thallus in his herbarium, now in LBL. This specimen is now the only extant original material and can be considered as the holotype. The neotypification by Clerc (1994) is therefore invalid.

\section{Usnea subscabrosa Nyl. ex Motyka}

Lich. Gen. Usnea Stud. Monogr., Pars Syst. 2: 313 (1938); type: Portugal, 1877, Newton (H!-holotype); \%C/\%M/\%A: 14/13.5/45; chemistry: usnic and protocetraric acids.

Usnea santae-annae Motyka, Lich. Gen. Usnea Stud. Monogr., Pars Syst. 2: 315 (1938); type: Brasilia, Matto Grosso, Santa Anna da Chapada, in 'cerrado' et in margine silve, 1894, Malme (S!-holotype); \% C/\%M/\%A: 13/15.5/44; chemistry: usnic, protocetraric and fumarprotocetraric acids.

This very distinctive species (Clerc 1992) is known to occur in south-western Europe, Macaronesia and north-eastern North America. Usnea santa-annae is morphologically and chemically identical with this species and therefore $U$. subscabrosa is new for South America.

\section{Usnea wirthii $\mathbf{P}$. Clerc}

Saussurea 15: 33-36 (1984); type: France, Aude, forêt des Fanges à l'est de Quillan, Abies, Fagus, Sorbus aria, S. aucuparia, Ilex, Quercus ilex, 18 vii 1951, E. Frey (BERN!-holotype); \% C/\%M/ $\%$ A: $7 \cdot 5 / 26.5 / 32$; chemistry: usnic and psoromic acids, \pm unidentified fatty acid.

Usnea quercina Bystrek \& Górzyńska, Ann. Univ. Mariae Curie Skłodowuska, Sect. 3, Biol. 17: 184 (1985); type: France, Gironde, La Haillan sur Quercus, thallus 'Lub 11', 1930, Jeanjean (LBL!-lectotype, selected here); $\% \mathrm{C} / \% \mathrm{M} / \% \mathrm{~A}: 8 / 32 \cdot 5 / 19$; chemistry: usnic and psoromic acids.

The holotype of $U$. quercina as designated by their authors is heterogeneous and consists of two thalli: the smaller thallus ('Lub 11 ') is $U$. wirthii with psoromic acid; the second thallus ('Lub 12') corresponds to $U$. esperantiana P. Clerc with salazinic and bourgeanic acids in the medulla (Clerc 1992). There are in the protologue no unequivocal elements (the central axis of the $U$. wirthii specimen is not yellow and no TLC had been done) that would allow one to distinguish which of the two specimens the authors meant to describe. Furthermore, one specimen given in the protologue (Portugal, Estramadura, Sintra, 1931, Nilsson) is U. cormuta Körb. and another one (F, Landes, Moliets, 1950, Frey) is a mixed population of $U$. esperantiana and 
U. comuta. All this shows that Bystrek \& Gorzynska (1985) had a somewhat fluid concept of their species. The name $U$. quercina has not been widely adopted, whereas $U$. esperantiana has become well-established (e.g. in Purvis et al. 1992). Therefore, in the interests of nomenclatural stability, I have chosen to lectotypify $U$. quercina on the element pertaining to $U$. wirthii.

I found in $\mathrm{H}$ a specimen of $U$, wirthii collected in 1932 by $\mathrm{G}$. Looser in Central Chile (chemistry: usnic and psoromic acids), extending considerably the distribution of this very characteristic species, which is then new for South America. The psoromic acid chemotype is dominant in Europe (Clerc $1984 b$; Clerc \& Diederich 1991; Purvis et al. 1992) whereas the norstictic acid chemotype is dominant elsewhere as exemplified by studies in British Columbia (Halonen et al. unpublished). Sometimes the axis and the periaxial medulla appear to lack the yellow pigment, as for instance in the lectotype of $U$. quercina (see above). However, the small size of the mature thalli (up to $4 \mathrm{~cm}$ ), the superficial soralia (usually larger than half the diameter of the branch bearing them), the absence or near absence of isidiomorphs, the slightly swollen branches that are constricted at ramification points, the thin cortex and the lax medulla are diagnostic characters for $U$. wirthii.

Selected specimens examined: Chile: Aconcagua: Limache, $200 \mathrm{~m}, 10$ iv 1932, Looser $(\mathrm{H})$. -- Peru: ruins of Machu Pichu, on twigs, 25 xii 1990, P. B. Topham (E).

I am very grateful to Prof. T. Ahti and Prof. J. Bystrek and their staffs for the facilities they granted to me in $\mathrm{H}$ and LBL, respectively. Particular thanks are due to the friends of the Botanical Garden of Geneva who made possible the visit to Helsinki. I wish to thank Helene Geser for technical support with TLC and Dr Loraine Kohorn (Duke University) for correcting the English of the manuscript.

\section{REFERENCES}

Bystrek, J. (1970) Rozmieszczenie Usnea silesiaca Motyka w Europe. Annales Unicersitatis Mariae Curie-Sktodowska, Sect. 3, Biologia 25: 167-169.

Bystrek, J. \& Górzyńska, K. (1985) Espèces de la section Glabratae (genus Usnea Wigg. em Ach.) en Europe. Annales Universitatis Mariae Curie-Sktodozska, Sect. 3, Biologia 40: 175-191.

Bystrek, J., Górzyńska, K. \& Sawa, K. (1981) Gatunki rodzaju Usnea Wigg. emend. Ach. w Makroregionie Lubelskim. Annales Universitatis Mariae Cume-Sklodonska, Sect. 3, Biologia 36: $135-145$.

Clerc, P. (1984a) Contribution à la revision de la systématique des usnées (Ascomycotina, Lsnea) d'Europe. I. Usnea florida (L.) Wigg. em P. Clerc. Cmptoganie, Brologic et Lichénologie 5: $333-360$

Clerc, P. (1984b) Usnea wirthii-A new species of lichen from Europe and North Africa. Saussurea 15: $33-36$

Clerc, P. (1987a) Systematics of the Usnea fragilescens aggregate and its distribution in Scandinavia. Nordic Fotmal of Botany 7: 479-495.

Clerc, P. (1987b) On the morphology of soralia in the genus Usnea. Bibliotheca lichenologica 25: 99-102.

Clerc, P. (1991) Usnea madeirensis Motyka (ascomycete lichénisé): une espéce méconnue de l'Europe et de l'Amérique du Nord. Candollea 46: 427-438.

Clerc, P. (1992) Some new or interesting species of the genus Usnea (lichenised Ascomycetes) in the British Isles. Candollea 47: 513-526.

Clerc, P. (1994) Comment Usnea mutabilis Stirt., une espèce nord-américaine, se cache en Europe sous le nom d'Usnea marocana Motyka-Une contribution à la systématique du genre Lsnea (ascomycètes lichénisés). Bulletin de la Société Linnéenne de Provence 45: 309-316.

Clerc, P. \& Diederich, P. (1991) Usnea wirthii P. Clerc new to North America and the British Isles. Lichenologist 23: 405-407. 
Culberson, C. F. \& Ammann, K. (1979) Standardmethode zur Dünnschichtchromatographic von Flechtensubstanzen. Her:ogia 5: 1-24.

Culberson, C. F. \& Johnson, A. (1982) Substitution of methyl tert.-butyl ether for diethyl ether in the standardized thin-layer chromatographic method for lichen products. foumal of Chromatography 238: 483-487.

Halonen, P. \& Puolasmaa, A. (1995) The lichen genus Usnea in eastern Fennoscandia. I. Usnea hirta. Annales Botanici Fennici 32: 127-135.

Jorgensen, P. M., James, P. \& Jarvis, C. E. (1994a) Proposals to reject or conserve 26 Linnaean names of lichenized ascomycetes. Taxon 43: 646-654.

Jorgensen, P. M., James, P. \& Jarvis, C. E. (1994b) Linnaean lichen names and their typification. Botanical foumal of the Linnean Society 115: 261-405.

Motyka, J. (1930) Materialy do flory porostow Slaska. Wydaznictwo Muzeum Slaskiego Katowicach 3(3): 5-26.

Motyka, J. (1936-1938) Lichenum Generis Usnea, Studium Monographicum. Pars systematica. 2 vols. Leopoli: privately printed.

Myllys, L. (1994) Usnea glabrata (lichenized Ascomycotina) in East Fennoscandia. Acta Botanica Fennica 150: 125-130.

Purvis, O. W., Coppins, B. J., Hawksworth, D. L., James, P. W. \& Moore, D. M. (1992) The Lichen Flora of Great Britain and Ireland. London: Natural History Museum Publications.

Swinscow, T. D. V. \& Krog, H. (1975) The Usnea undulata aggregate in East Africa. Lichenologist 7: $121-138$.

Walker, F. (1985) The lichen genus Usnea subgenus Neuropogon. Bulletin of the British Museum (Natural Histom), Botany: 13: 1-130.

Accepted for publication 26 September 1996 
Downloaded from https:/www.cambridge.org/core. University of Basel Library, on 11 Jul 2017 at 09:09:09, subject to the Cambridge Core terms of use, available at https:/www.cambridge.org/core/terms. https://doi.org/10.1006/lich.1996.0075 